\title{
Foreign Trade Situation of Nepal
}

\author{
Shiva Sharan Shrestha'
}

\begin{abstract}
This study analyzes the growth, direction and trade balance of Nepal's foreign trade for the period 2005/6 to 2014/15. The study finds that the import has grown rapidly (at an annual average rate of 17\%) and the import at snail's pace (at an annual rate of 4\%) over the study period. As a result the trade balance is negative and growing every year. Such a trend can't sustain for long. Further, Nepal's foreign trade is too much dependent (exceeding two-third of both export and import) on India which needs to be diversified to rest of the world.
\end{abstract}

Key words: Foreign trade, Trade diversification, Trade balance.

\section{INTRODUCTION}

Foreign trade refers the business of imports and exports with foreign countries. In other words, it is international trade which deals the transaction of goods including services, financial flows and the movement of factors of production like labor, capital and entrepreneurship. It provides capital goods and raw materials, transmits technological knowhow and promotes relationship among different countries. It also enhances product quality and benefits the countries with respect to production, consumption, competition, employment, and income (Bashyal, 2008).

The foreign trade of Nepal was limited with Tibet and India during Lichhivi and Malla period. It could not flourish during Rana period as Nepal remained isolated with the world. Nepal started expanding trade with foreign countries after she overthrew autocratic Rana regime in 2007 B. S. By now it has expanded it trade with more than 150 countries of all continents. However, Nepal's foreign trade is concentrated with her neighbors mainly with India.

\section{OBJECTIVES AND METHODS OF THE STUDY}

The objective of this write up is to examine Nepal's foreign trade situation and make recommendations to improve it. Specifically, this study attempts to find out the growth

Mr. Shiva Sharan Shrestha is Associate Professor at Public Youth Campus, Tribhuvan University.

Email. shivasharnshrestha@gmail.com 
and direction of foreign trade of Nepal, and analyze the Nepal's trade balance with India.

The study is based on secondary data collected from Economic Survey published by Ministry of Finance of the Government of Nepal. The study period is 10 fiscal years (2005/06 to 2014/15). Annual growth rates, compound growth rates and export to import ratio have been calculated to examine the growth pattern of the foreign trade and trade balance.

\section{DATA ANALYSIS}

\section{Growth of foreign trade}

Table 1 and Figure 1 present Nepal's import and export data for a period of 10 years (2005/6 - 2014/15). Both export and import have grown over the study period, but the growth of import is rapid as compared to export. The export was Rs 6,023 crore (10 million) in 2005/6 which increased to 8,309 crore in $2014 / 15$. The import increased from 17078 crore in $2005 / 6$ to Rs 67,452 crore in $2014 / 15$. Over the study period, the export increased by 1.38 times or an annual average growth rate of $4.09 \%$ while the import increased by 3.95 times or an annual average growth rate of $16.91 \%$. Further, the growth in export is erratic with four negative growths whereas the import has increased every year. The rapid increase in import over export has led to growing trade deficit.

Table 1: Growth of Foreign Trade of Nepal

(Rs in 10 million)

\begin{tabular}{|c|c|c|c|c|c|c|}
\hline \multirow{3}{*}{ Year } & \multirow{2}{*}{\multicolumn{2}{|c|}{ Total Trade }} & \multicolumn{4}{|c|}{ Total } \\
\hline & & & \multicolumn{2}{|c|}{ Export } & \multicolumn{2}{|c|}{ Import } \\
\hline & Amount & $\begin{array}{c}\text { Growth rate } \\
(\%)\end{array}$ & Amount & $\begin{array}{c}\text { Growth rate } \\
(\%)\end{array}$ & Amount & $\begin{array}{c}\text { Growth rate } \\
(\%)\end{array}$ \\
\hline $2005 / 6$ & 23101 & & 6023 & & 17078 & \\
\hline $2006 / 7$ & 25408 & 9.98 & 5938 & -1.41 & 19469 & 14.00 \\
\hline $2007 / 8$ & 28120 & 10.68 & 5927 & -0.20 & 22194 & 13.99 \\
\hline $2008 / 9$ & 35217 & 25.24 & 6770 & 14.23 & 28447 & 28.18 \\
\hline $2009 / 10$ & 43576 & 23.74 & 6082 & -10.15 & 37493 & 31.80 \\
\hline $2010 / 11$ & 46051 & 5.68 & 6434 & 5.78 & 39618 & 5.67 \\
\hline $2011 / 12$ & 53593 & 16.38 & 7426 & 15.42 & 46167 & 16.53 \\
\hline $2012 / 13$ & 56912 & 6.19 & 7483 & 0.77 & 49429 & 7.07 \\
\hline $2013 / 14$ & 73020 & 28.30 & 8915 & 19.13 & 64105 & 29.69 \\
\hline $2014 / 15$ & 75761 & 3.75 & 8309 & -6.80 & 67452 & 5.22 \\
\hline \multicolumn{2}{|c|}{ Annual growth rate (\%) } & 14.44 & & 4.09 & & 16.91 \\
\hline
\end{tabular}


80 I PYC Nepal Journal of Management, August 2016, Vol. IX, No. 1

Figure 1: Growth of Import and Export of Nepal

\section{Direction of foreign trade}

The direction of foreign trade has been analyzed between India vis-à-vis other countries. Nepal's foreign trade is very much concentrated towards India. During the study period, almost two-third of the export is with India and the rest is with the rest of the world. The

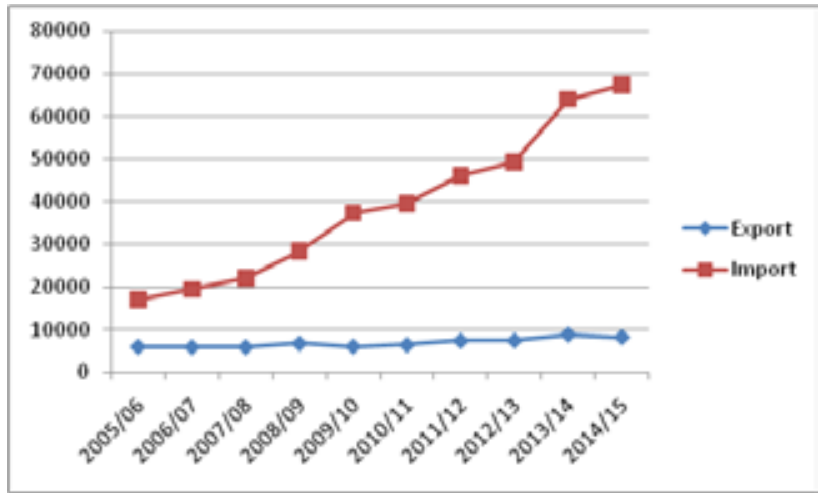
share of export to India is about $67 \%$ during the study period implying heavy dependence in one country. It also indicates our export diversification strategies have not been successful. The scenario of import trade is worse than the export. The import has increased almost four times in a period of 10 years (2005/6- 2014/15. Further, Nepal's reliance on import from India has increased from $63 \%$ in $2005 / 6$ to $73 \%$ in $2014 / 15$ while the export is almost stagnant at around $67 \%$ during the same period. These facts indicate failure in trade diversification policies. The hardship the Nepalese people had to face during 2014/15 due to blockade by India was the result of our failure in foreign trade policy.

Table 2: Trade Diversification with India and Other Countries

(Rs 10 million)

\begin{tabular}{|c|c|c|c|c|c|c|c|c|c|c|c|c|}
\hline \multirow[b]{3}{*}{ Year } & \multicolumn{6}{|c|}{ Export } & \multicolumn{6}{|c|}{ Import } \\
\hline & \multirow{2}{*}{$\begin{array}{c}\text { Total } \\
\text { Amount }\end{array}$} & \multicolumn{3}{|c|}{ Export to India } & \multicolumn{2}{|c|}{$\begin{array}{l}\text { Export to Other } \\
\text { Countries }\end{array}$} & \multirow{2}{*}{$\begin{array}{c}\text { Total } \\
\text { Amount }\end{array}$} & \multicolumn{3}{|c|}{ Import from India } & \multicolumn{2}{|c|}{$\begin{array}{l}\text { Import from Other } \\
\text { Countries }\end{array}$} \\
\hline & & Amount & $\begin{array}{l}\text { Growth } \\
\text { rate }\end{array}$ & $\begin{array}{c}\% \text { of } \\
\text { total } \\
\text { export }\end{array}$ & Amount & $\begin{array}{l}\text { Growth } \\
\text { rate }\end{array}$ & & Amount & $\begin{array}{l}\text { Growth } \\
\text { rate }\end{array}$ & $\begin{array}{l}\% \text { of } \\
\text { total } \\
\text { import }\end{array}$ & Amount & $\begin{array}{l}\text { Growth } \\
\text { rate }\end{array}$ \\
\hline $2005 / 6$ & 6023 & 4071 & & 67.59 & 1952 & & 17078 & 10714 & & 62.74 & 6364 & \\
\hline $2006 / 7$ & 5938 & 4173 & 2.49 & 70.27 & 1765 & -9.56 & 19469 & 11587 & 8.15 & 59.51 & 7882 & 23.86 \\
\hline $2007 / 8$ & 5927 & 3856 & -7.60 & 65.05 & 2071 & 17.31 & 22194 & 14238 & 22.87 & 64.15 & 7956 & 0.94 \\
\hline $2008 / 9$ & 6770 & 4101 & 6.35 & 60.57 & 2669 & 28.88 & 28447 & 16244 & 14.09 & 57.10 & 12203 & 53.38 \\
\hline $2009 / 10$ & 6082 & 3999 & -2.47 & 65.75 & 2083 & -21.96 & 37493 & 21771 & 34.03 & 58.07 & 15722 & 28.84 \\
\hline 2010/11 & 6434 & 4336 & 8.42 & 67.39 & 2098 & 0.71 & 39618 & 26193 & 20.31 & 66.11 & 13425 & -14.61 \\
\hline $2011 / 12$ & 7426 & 4961 & 14.42 & 66.81 & 2465 & 17.48 & 46167 & 29939 & 14.30 & 64.85 & 16228 & 20.88 \\
\hline $2012 / 13$ & 7483 & 5100 & 2.79 & 68.15 & 2383 & -3.30 & 49429 & 36703 & 22.59 & 74.25 & 12726 & -21.58 \\
\hline $2013 / 14$ & 8915 & 5961 & 16.89 & 66.87 & 2954 & 23.94 & 64105 & 47795 & 30.22 & 74.56 & 16310 & 28.16 \\
\hline $2014 / 15$ & 8309 & 5587 & -6.29 & 67.23 & 2723 & -7.83 & 67452 & 49166 & 2.87 & 72.89 & 18286 & 12.12 \\
\hline
\end{tabular}


Figure 2: Trade Diversification: India vis-à-vis Other Countries in 2005/6 and 2014/15

Trade balance

Table 3 and Figure 3 presents trade balance data between Nepal and India along with other countries for the study period. The rapid rate of import and export at snail's pace has resulted into widening trade deficit particularly with India. The aggregate trade balance was negative by Rs 11,055 crore in 2005/6 which has increased by more than five times to Rs 59,143 crore in $2014 / 15$. The export/import ratio (export as a fraction of import) was 0.3527 in 2005/6 has deteriorated every year (except in 2010/11) and fallen to 0.1232 in 2014/15.

A look at trade balance with India shows that the trade balance was negative by Rs 6,643 crore in $2005 / 6$ which jumped by more than six fold and reached to Rs 43,579 crore in 2014/15. The export to import ratio has fallen from 0.3800 to 0.1136 in the same period. The trade deficit with other countries is also growing, but it is not as grave as with India.

Table 3: Trade Balance with India and Other Countries

(Rs in 10 million)

\begin{tabular}{|c|c|c|c|c|c|c|c|c|c|c|c|c|}
\hline \multicolumn{5}{|c|}{ Total } & \multicolumn{4}{|c|}{ India } & \multicolumn{4}{|c|}{ Other countries } \\
\hline $\begin{array}{l}\text { Fiscal } \\
\text { Year }\end{array}$ & Export & Import & Balance & $\begin{array}{l}\text { E/l } \\
\text { ratio }\end{array}$ & Export & Import & Balance & $\begin{array}{c}\mathrm{E} / \mathrm{l} \\
\text { ratio }\end{array}$ & Export & Import & Balance & $\begin{array}{l}\text { E/l } \\
\text { ratio }\end{array}$ \\
\hline $2005 / 06$ & 6023 & 17078 & -11055 & 0.3527 & 4071 & 10714 & -6643 & 0.3800 & 1952 & 6364 & -4412 & 0.3067 \\
\hline $2006 / 07$ & 5938 & 19469 & -13531 & 0.3050 & 4173 & 11587 & -7414 & 0.3601 & 1765 & 7882 & -6117 & 0.2240 \\
\hline $2007 / 08$ & 5927 & 22194 & -16267 & 0.2670 & 3856 & 14238 & -10382 & 0.2708 & 2071 & 7956 & -5885 & 0.2603 \\
\hline $2008 / 09$ & 6770 & 28447 & -21677 & 0.2380 & 4101 & 16244 & -12143 & 0.2524 & 2669 & 12203 & -9534 & 0.2187 \\
\hline $2009 / 10$ & 6082 & 37493 & -31411 & 0.1622 & 3999 & 21771 & -17772 & 0.1837 & 2083 & 15722 & -13639 & 0.1325 \\
\hline $2010 / 11$ & 6434 & 39618 & -33184 & 0.1624 & 4336 & 26193 & -21856 & 0.1655 & 2098 & 13425 & -11327 & 0.1563 \\
\hline $2011 / 12$ & 7426 & 46167 & -38741 & 0.1609 & 4961 & 29939 & -24978 & 0.1657 & 2465 & 16228 & -13763 & 0.1519 \\
\hline $2012 / 13$ & 7483 & 49429 & -41946 & 0.1514 & 5100 & 36703 & -31603 & 0.1390 & 2383 & 12726 & -10343 & 0.1873 \\
\hline $2013 / 14$ & 8915 & 64105 & -55190 & 0.1391 & 5961 & 47795 & -41833 & 0.1247 & 2954 & 16310 & -13356 & 0.1811 \\
\hline 2014/15 & 8309 & 67452 & -59143 & 0.1232 & 5587 & 49166 & -43579 & 0.1136 & 2723 & 18286 & -15564 & 0.1489 \\
\hline
\end{tabular}


Figure 3: Nepal's Trade Balance (Total and with India)

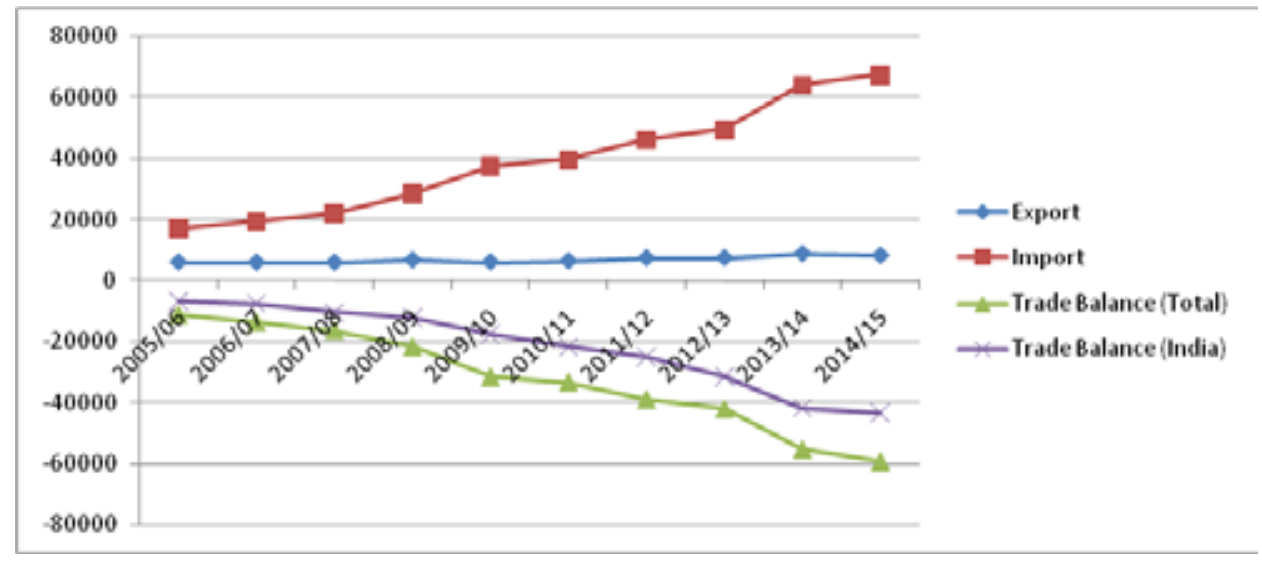

\section{DISCUSSIONS AND RECOMMENDATIONS}

The state of the growth of foreign trade of Nepal is evident from the fact that the total trade has grown at an annual rate of $14.44 \%$ while the export has grown by meager 4 percent and import by almost $17 \%$. It urgently calls for boasting export so that the contribution of export trade is fair in total trade. Nepal should focus on high value products to avoid high transport cost due to land-lockedness of the country.

The excessive dependence on one country i. e. India must be reduced through third country diversification of import as well as export trade. Both the development of import-substituting industries and the export of goods and services must be promoted. For example, the development and export of hydropower can reduce import of fuel as well as increase export.

\section{REFERENCES:}

Bashyal, R. (2008). Nepal Trade Expansion among SAARC Countries and Regional Trading Arrangement. Kathmandu: Nepal Rastra Bank.

Bajgain, K. R. (2016). Reviving exports. Republica, August 25.

Ghimire, L. S. (2016). Nepal's widening trade deficit. Kathmandu: National planning commission. Ministry of Finance (2015). Economic Survey 2014/15. Kathmandu: Government of Nepal. NRB (2016). Quarterly Economic Bulletin, 50(3). 